 \\ Мотив изгнания в кубино-американской литературе
}

Шкилёв Р. Е., Дулалаева И. Ю.

Аннотация. Статья посвящена рассмотрению особенностей репрезентации мотива изгнания в кубино-американской литературе. Эксплицируются философские аспекты изгнания, устанавливается взаимосвязь между чувством замещения у пожилых людей и географическим изгнанием. Показана специфика переживания изгнания пожилыми персонажами К. Гарсиа, А. Менендес и С. Родригес Миланес. Цель исследования состоит в определении специфики переживания изгнания пожилыми кубино-американцами. Научная новизна работы заключается в том, что впервые детально анализируется феномен изгнания в кубино-американской литературе. Полученные результаты показали, что в этнических диаспорах латиноамериканского происхождения пожилые женщины и мужчины по-разному переживают изгнание.

\section{Motive of Exile in the Cuban American Literature}

\author{
Shkilev R. E., Dulalaeva I. Y.
}

Abstract. The article is devoted to the consideration of the peculiarities of the exile motive representation in the Cuban American literature. The philosophical aspects of exile are explicated, the correlation between the feeling of replacement in the elderly and geographical exile is ascertained. The specificity of the emotional experience of exile by the elderly characters C. Garcia, A. Menendez and S. Rodriguez Milanes is shown. The aim of the study is to determine the specificity of the emotional experience of exile by the elderly Cuban Americans. The scientific originality of the work lies in the fact that for the first time the phenomenon of exile in the Cuban American literature is analysed in detail. The results have shown that in ethnic diasporas of the Hispanics, elderly women and men experience exile in different ways.

\section{Введение}

Изучение различных аспектов поиска идентичности в ситуации культурного пограничья продолжает сохранять актуальность (Левченко, 2017; Шкилёв, 2019; Amery, 1994). Термин «изгнание» или «ссылка» получил широкую трактовку в современных исследованиях и используется для описания как различных типов социального взаимодействия, так и возрастных изменений. Современные американские литературоведы, опираясь на теоретический труд М. Хайдегера (Heidegger, 1996) «Пребывая во времени», предпринимают попытки литературоведческого анализа специфики переживания пожилыми персонажами «естественного изгнания» в семье и обществе. Таким образом, актуальность данного исследования обусловлена необходимостью разработки проблемы изгнания с позиций литературоведения в контексте культурного пограничья. В ходе исследования нами решаются такие задачи, как изучение философских аспектов изгнания, определение специфики опыта изгнания персонажами рассматриваемых произведений, выявление гендерных особенностей переживания изгнания представителями кубино-американской диаспоры.

Практическая значимость работы: результаты исследования могут найти применение в вузах гуманитарного профиля при изучении истории литературы США и спецкурсов по иммигрантской литературе, сопоставительной культурологии. В процессе исследования нами были использованы следующие методы: философского анализа (на этапе работы с философской литературой), сопоставительный (при рассмотрении персонажей из нескольких произведений), интегративный (при определении гендерной специфики поведения персонажей на основе изучения культурного контекста и теоретической философской базы).

Решение поставленных задач стало возможным благодаря теоретической базе, представленной трудами Мартина Хайдегера (Heidegger, 1996), Андре Асимана (Aciman, 2000), Алехандро Валлеги (Vallega, 2003). В данных работах анализируются философские аспекты изгнания, подвергаются рассмотрению существующие в современной философии и культурологии подходы к трактовке феномена изгнания, излагаются 
основные положения теории изгнания. Несомненный интерес с литературоведческой точки зрения представляет исследование Эланы Гайнор (Gainor, 2016), в котором эксплицируется специфика кубино-американской иммигрантской литературы.

\section{Основная часть}

Какие бы тесные ассоциации ни вызывало слово «изгнание» с внутренней дисгармонией и чувством утраты, для читателя, который сталкивается с подобным явлением исключительно на примере художественного произведения, трудно ощутить всю горечь истинной утраты в полной мере. В произведениях, повествующих о пожилых протагонистах, мотив изгнания тесно связан с проблемой поиска идентичности и явлением двойной идентичности. Пожилые персонажи находятся в центре повествования произведений «Кубинский король» (“King of Cuba”) Кристины Гарсиа (Garcia, 2013), «На Кубе я был немецким пастухом» (“In Cuba I Was a German Shepherd”) Аны Менендес (Menendez, 2001) и «Абуэла Мариэлита» (“Abuela Marielita”) Сесилии Родригес Миланес (Rodriguez Milanes, 2009).

Источником материала для повествования всех трёх авторов является их личный опыт. Герои всех произведений живут в том же самом культурном пространстве, в котором живут и сами писатели. Кубино-американская литература освещает традиционную для иммигрантской литературы тематику: тоску по исторической родине, сопровождающуюся попытками преодолеть культурные и социальные различия в стране, ставшей второй родиной.

Американские литературоведы и культурологи не ставят знака равенства между понятиями «изгнание» (exile) и иммиграция. Так как опыт изгнания кубинцев, живущих в США, довольно уникален в силу исторических и политических особенностей, а также географического положения, данная тематика занимает важное место в кубино-американской литературе. Представители крупной кубино-американской общины в Майами, испытывая горячую любовь к Кубе, имеют ясное представление о том, что значит быть в изгнании (при этом изгнание не всегда выступает здесь синонимом слова «иммиграция» в прямом смысле этого слова). Именно то обстоятельство, что Куба находится всего лишь на расстоянии 90 миль от побережья США, заставляет кубино-американцев ощущать разрыв между местом, где сформировалась их идентичность, и местом, где они вынуждены жить после революции 1959 года.

В наиболее известном романе «Мечтая по-кубински» (“Dreaming in Cuban”) показаны три поколения женских персонажей. Бабушка играет важную роль в повествовании. Тем не менее, темы изгнания и возраста человека не являются центральными в романе. В более позднем романе «Кубинский король», показывая пожилых протагонистов, автор углубляется в тему старости в изгнании. К. Гарсиа изображает Гойо сильной личностью. Несмотря на пожилой возраст, ему удаётся сохранить определённый уровень независимости, образ мачо и финансовое благополучие. Таким образом, внимание читателя не акцентируется на стареющем теле или социальных аспектах старения.

В повести «На Кубе я был немецким пастухом» Ана Менендес (Menendez, 2001) детально изображает весь ужас естественного изгнания. Несмотря на небольшой объём повести, автору удаётся детально осветить социальную и эмоциональную борьбу, которую пожилой иммигрант вынужден вести, даже будучи среди кубинской диаспоры в Майами. Хоть писательница и широко использует юмор, целостная картина из мыслей и воспоминаний Максимо даёт понять читателю, что возраст является изгнанием с ментальной и физиологической точек зрения. В центре внимания двух описанных выше произведений находятся истории иммигрантов-мужчин пожилого возраста, которые приехали в Штаты в конце 50-х - начале 60-х годов.

Повесть Сесилии Родригес Миланес (Rodriguez Milanes, 2009) «Абуэла Мариэлита» представляет собой попытку взглянуть на проблему изгнания глазами пожилой женщины. Соледад не принадлежит к первой волне кубинских иммигрантов и не разделяет идеологических установок и культурных ценностей Гойо и Максимо. Тем не менее она вынуждена вести борьбу за сохранение своей идентичности. Возраст и пол протагониста играют исключительно важную роль в произведении. Так как Соледад самая молодая их трёх персонажей, в романе отсутствуют описания старости в чистом виде, по мере развития сюжета читатель встречает косвенные признаки начинающегося «естественного изгнания». Это традиции, которые важны для Соледад, но которые не соблюдает молодое поколение, это постаревшие друзья, а также недостаток внимания со стороны семьи.

В литературоведении рассмотрению подвергаются примеры политического изгнания и его воздействие на особенности восприятия человеком самого себя, воспоминаний и нового места жительства. Очень часто объектом анализа становится то, как персонаж постоянно сравнивает прошлое и окружающую его среду. Также рассматриваются политические, исторические и географические аспекты изгнания. Проблеме поиска идентичности кубино-американцами посвящена работа Хорхе Дуани (Duany, 1993). Х. Дуани описывает опыт кубино-американцев, которым удалось добиться успеха в погоне за «американской мечтой». Многие кубиноамериканцы рассматривают американскую культуру как некую обобщённую форму с точки зрения иммигрантского опыта. Американская реальность оказывает влияние на воспоминания и способствует романтизации образа родины. Таким образом, в описанных выше статьях показано, как представители диаспоры продолжают мечтать о Кубе, живя в Америке.

Заслуживает упоминания диссертация Эланы Гайнор (Gainor, 2016) на тему «Кубино-американская иммигрантская литература: места, карты и поиск пути» (“The Space of Cuban-American Exile Narratives: Places, Maps 
and Wayfinding”). Автор устанавливает чёткую взаимосвязь между персонажами, их кубинской и американской идентичностью и испытываемым ими чувством тоски. В работе делается акцент на ярко выраженные пространственные отношения между Кубой и Америкой (особенно это касается Майами). После многих лет формирования второй идентичности в США корни кубино-американцев напоминают им о жизни, которая у них была когда-то в прошлом. При этом воспоминания о Кубе не всегда являются точными, часто они носят идеализированный характер. Э. Гайнор приходит к выводу о том, что физическое ощущение пространства и иммигрантская идентичность тесно связаны между собой.

В ряде зарубежных исследований используется термин «теория изгнания» (exile studies). Так, Андре Асиман (Aciman, 2000) определяет изгнание как неестественное состояние, когда жизнь в чужой культуре, чужом обществе и чужой языковой среде препятствует формированию целостной идентичности. В этом смысле кубинская диаспора в Майами не является исключением. Характеризуя неестественное для человека состояние, А. Асиман описывает изгнание как «постоянную мимолётность» (permanent transients). По его мнению, политические, культурные и национальные связи с родиной влияют на иммигранта, где бы он ни находился.

Значительный вклад в разработку теории изгнания внёс оказавшийся в изгнании чилийский исследователь Алехандро Валлега (Vallega, 2003). Он описывает опыт изгнания сквозь призму теории экзистенциальной феноменологии Мартина Хайдеггера. В книге «Хайдеггер и проблема пространства: взгляд из изгнания» ("Heidegger and the Issue of Space: Thinking on Exilic Grounds") А. Валлега привлекает к анализу разработанную М. Хайдеггером концепцию бытия и делает вывод о том, что внутреннее «я» человека, находящегося в изгнании, претерпевает постоянные изменения, вызванные влиянием пространства. Чужое пространство, в котором иммигрант сталкивается с чужим для него языком, культурой и традициями, заставляет внутренний мир постоянно изменяться. С позиций теории М. Хайдеггера, в которой делается акцент на постоянном, неизменном в бытии человека, взгляд человека в изгнании на окружающую его среду является непостоянным. Таким образом, воздействие пространства на бытие и внутренний мир человека находит отражение в идентичности.

По М. Хайдеггеру, бытие человека формируется во времени - события непосредственно формируют идентичность. Человек в изгнании чувствует себя потерянным, в то время как его внутреннее «я» продолжает функционировать, сохраняя пространственные отношения. Ключевыми факторами, определяющими внутренний мир человека в изгнании, являются его потенциал и бытие относительно смерти (being towards death). Даже когда пожилые люди живут с осознанием смерти, они тем не менее обладают определённым потенциалом.

Американское общество отодвигает пожилых людей на обочину жизни, помещая их в дома престарелых, создавая общины для пожилых и игнорируя их взгляды и традиции. Языковые, культурные, правовые различия между Кубой и США, а также различия в структуре общества в целом определяют двойную идентичность кубино-американцев. На бытие персонажей анализируемых нами произведений влияет их опыт повседневной жизни в США. Гойо живёт между Нью-Йорком и Майами и поглощён кубинской политической жизнью, испытывая всё возрастающее желание увидеть смерть Фиделя Кастро до того, как он сам уйдет из жизни.

Другой протагонист - Максимо - проводит время в парке Домино в Майами, где он общается с друзьями. А. Менендес создаёт социальную среду, в которой Максимо не может не замечать отношения к пожилым людям в американском обществе. Ему постоянно напоминают о его месте в обществе. С. Родригес Миланес помещает Соледад в дом её дочери. Она погружена в воспоминания о Кубе. Общаясь с членами семьи и постояльцами дома, Соледад сталкивается с американским обществом. В каждом из анализируемых произведений реакция персонажей на изгнание и созданные писателями образы полностью соотносятся с основными положениями теории изгнания.

Общество видит пожилых людей в роли мудрых учителей или отшельников. Протагонисты-мужчины описываются с несколько негативным оттенком. Гойо кажется немного сумасшедшим, а Максимо - рассерженным. В случае с Соледад имеет значение её принадлежность к женскому полу. Она выступает в роли любящей бабушки. Читатель наблюдает процесс социальной идеализации, который подразумевает, что пожилые люди выбирают одну из ролей, предписываемых обществом. Однако, стремясь в целом соответствовать предписываемому обществом идеалу, пожилые люди могут проявлять субъективность. Соледад проявляет свою субъективность, отказывая в просьбе дочери, хотя подобный отказ вступает в конфликт с образом идеальной «любящей бабушки».

Идеализация образа пожилой женщины и пожилого мужчины является формой изгнания пожилых в обществе. Созданные обществом идеальные образы оказывают влияние на личное пространство персонажей, которое уменьшается по мере их старения. Пожилые становятся меньшинством в обществе. Так, например, игра пожилых мужчин в домино является формой выражения субъектности в собственной возрастной группе, а также способом борьбы с социальной изоляцией. В качестве одной из особенностей данной возрастной группы в сравнении с другими возрастными группами исследователи выделяют иной взгляд на ценности. Пожилые не говорят о возможностях и развитии, в этом заключается основная особенность их субъективного выбора. Совершаемые ими действия часто носят характер ритуала.

Соледад осознает, что принадлежит к меньшинству и окружающие считают, что у неё нет потенциала. Семья относится к ней как к пожилой служанке. Она выполняет всю работу по дому, но когда она пытается выразить собственное мнение по поводу материальных трат дочери, родственники воспринимают её как старомодного и неразумного человека. Пожилых людей объективизирует окружающее общественное пространство, определяя их место в обществе против их воли. Соледад представляет собой меньшинство в доме своей семьи и постоянно сталкивается с неуважением. 
По мнению де Бовуар (de Beauvoir), процесс старения способствует формированию у мужчин отдельной формы инаковости (otherness). С утратой мужчиной власти он становится гораздо в большей степени просто объектом, чем женщина. В отличие от пожилой женщины пожилой мужчина не представляет для общества какой-либо ценности. Превращение в объект и является причиной развития инаковости у пожилых мужчин. По мере того как пожилые теряют свою субъектность, они превращаются в объекты, которые общество отправляет в изгнание, так как они не вносят существенного вклада в жизнь общества.

A. Менендес (Menendez, 2001) подчёркивает тот факт, что пожилые оказываются в положении меньшинства, создавая в повествовании соответствующую обстановку. Максимо проводит время в парке Домино с пожилыми друзьями-иммигрантами, в то время как туристы смотрят на них через забор как на животных в зоопарке. С одной стороны, парк Домино представляет собой то место, где Максимо в наибольшей степени сохраняет субъектность. С другой стороны, его нервирует отношение к нему как к достопримечательности. Особенно явно это проявляется в эпизоде, когда экскурсовод в громкоговоритель рассказывает о «старинной кубинской традиции неспешного времяпровождения за игрой в домино» (с. 26).

Персонаж К. Гарсиа Гойо изо всех сил старается сохранить свою мужественность. Экономический статус позволяет Гойо, несмотря на возраст, пользоваться определённой популярностью у женщин. Однако в глазах общества он представляет собой меньшинство. Гойо становится участником автомобильной аварии (виновником которой он не является), и в обществе возобновляются дискуссии о праве пожилых водить автомобиль. Общество влияет на субъектность персонажа, оно само присваивает пожилому мужчине более низкий статус. Потеря субъективного статуса не является выбором мужчины, это обуславливается соответствующей структурой общества, в которой пожилым отведено определённое место. Для мужчин инаковость и принадлежность к меньшинству выступают в качестве примеров естественного изгнания.

В отличие от мужчин возраст не оказывает такого значительного влияния на статус и самоощущение женщин. Женщины стараются всячески помогать своим детям в домашних делах, они легче переживают смену ролей, в результате которой они становятся объектом заботы детей. Мужчины же болезненно воспринимают утрату привычной социальной роли в обществе. Таким образом, «естественное» изгнание, вызванное вступлением в преклонный возраст, представляет собой постепенный процесс, на который описанные в анализируемых произведениях персонажи из кубино-американской диаспоры реагируют по-разному.

\section{Заключение}

В результате проведенного исследования нами были сделаны следующие выводы: 1) философская основа для описания различных аспектов изгнания была создана М. Хайдеггером и получила дальнейшее развитие в работах исследователей, работающих в междисциплинарной области, известной за рубежом как теория изгнания (exile studies); 2) специфика опыта изгнания персонажей рассматриваемых произведений в значительной степени определяется характером их родственных и духовных связей с исторической родиной, материальным положением, особенностями восприятия окружающими англо-американцами элементов кубинской культуры и самосознания, ближайшим социальным окружением; 3) существуют определённые гендерные особенности переживания изгнания представителями кубино-американской диаспоры, заключающиеся в различиях в социальной роли пожилых мужчин и женщин в семьях испаноязычных иммигрантов.

Перспективы дальнейшего исследования заключаются в более детальном изучении описания опыта изгнания в современной иммигрантской литературе США на примере различных диаспор.

\section{Источники | References}

1. Левченко С. О. Проблематизация идентичности: способы литературного конструирования: автореф. дисс. ... к. филол. н. Екатеринбург, 2017.

2. Шкилёв Р. Е. Автобиографические черты в кубино-американской художественной прозе // Филологические науки. Вопросы теории и практики. 2019. № 11.

3. Aciman A. Letters of Transit: Reflections on Exile, Identity, Language and Loss. N. Y.: The New Press, 2000.

4. Amery J. On Aging: Revolt and Resignation / trans. by J. D. Barrow. Bloomington - Indianapolis: Indiana University Press, 1994.

5. Duany J. Ethnic Identity in Recent Cuban-American Novels. Miami: Cuban Studies, 1993.

6. Gainor E. The Space of Cuban-American Exile Narratives: Places, Maps and Wayfinding: A Thesis. Oakland, 2016.

7. Garcia Ch. King of Cuba. N. Y.: Schribner, 2013.

8. Heidegger M. Being and Time. N. Y.: State University of New York Press, 1996.

9. Menendez A. In Cuba I Was a German Shepherd. N. Y.: Grove Press, 2001.

10. Rodriguez Milanes C. Abuela Marielita. N. Y.: IG Publishing, 2009.

11. Vallega A. Heidegger and the Issue of Space: Thinking on Exilic Grounds. Philadelphia: Pennsylvania State University Press, 2003. 


\section{Информация об авторах | Author information}

RU Шкилёв Роман Евгеньевич ${ }^{1}$, к. филол. н. Дулалаева Ирина Юльевна ${ }^{2}$

1,2 Казанский федеральный университет

EN Shkilev Roman Evgenievich ${ }^{1}, \mathrm{PhD}$ Dulalaeva Irina Yulievna ${ }^{2}$

${ }^{1,2}$ Kazan Federal University

${ }^{1}$ schkilef@gmail.com, 22firenedu@gmail.com

\section{Информация о статье | About this article}

Дата поступления рукописи (received): 19.11.2021; опубликовано (published): 28.02.2022.

Ключевые слова (keywords): изгнание; иммиграция; иммигрантская литература; диаспора; инаковость; exile; immigration; immigrant literature; diaspora; otherness. 